\title{
Canadian Public Health Laboratory Network laboratory guidelines for the diagnosis of neurosyphilis in Canada
}

\author{
Tom Wong MD MPH CCFP FRCPC ${ }^{1 *}$, Kevin Fonseca PhD D(ABMM) ${ }^{2}$, Max A Chernesky PhD FIDSA FAAM FCCM ${ }^{3}$, \\ Richard Garceau MD FRCPC ${ }^{4}$, Paul N Levett DSc (D)ABMM FCCM FAAM ${ }^{*}$, Bouchra Serhir MSc PhD ${ }^{6}$
}

\begin{abstract}
T Wong; K Fonseca, MA Chernesky, R Garceau, PN Levett, B Serhir. Canadian Public Health Laboratory Network laboratory guidelines for the diagnosis of neurosyphilis in Canada. Can J Infect Dis Mid Microbiol 2015;26(Suppl A):18A-22A.
\end{abstract}

Neurosyphilis refers to infection of the central nervous system by Treponema pallidum, which may occur at any stage. Neurosyphilis has been categorized in many ways including early and late, asymptomatic versus symptomatic and infectious versus non-infectious. Late neurosyphilis primarily affects the central nervous system parenchyma, and occurs beyond early latent syphilis, years to decades after the initial infection. Associated clinical syndromes include general paresis, tabes dorsalis, vision loss, hearing loss and psychiatric manifestations. Unique algorithms are recommended for HIV-infected and HIV-uninfected patients, as immunocompromised patients may present with serologic and cerebrospinal fluid findings that are different from immunocompetent hosts. Antibody assays include a VDRL assay and the FTA-Abs, while polymerase chain reaction for $T$. pallidum can be used as direct detection assays for some specimens. This chapter reviews guidelines for specimen types and sample collection, and identifies two possible algorithms for use with immunocompromised and immunocompetent hosts using currently available tests in Canada, along with a review of treatment response and laboratory testing follow-up.

Key Words: CD4; Congenital; CSF; HIV; Neurosyphilis

Teurosyphilis refers to infection of the central nervous system 1 (CNS)by Treponema pallidum, which may occur at any stage. Neurosyphilis was common in the pre-antibiotic era and accounted for $10 \%$ to $20 \%$ of patients admitted to asylums (1). The organism invades the CNS relatively early in the infection in approximately one-quarter of patients, based on studies involving the inoculation of cerebrospinal fluid (CSF) into rabbits $(2,3)$. While most patients will clear the organism from their CNS without treatment, an estimated $4 \%$ to $9 \%$ of patients may eventually develop late manifestations of neurosyphilis $(4,5)$.

\section{CLINICAL FINDINGS (APPENDIX 1)}

Neurosyphilis has been categorized in many ways including early and late, asymptomatic versus symptomatic and infectious versus noninfectious (6-8). Early neurosyphilis is a stage that coexists with a primary, secondary or early latent syphilis infection, with or without symptoms. In some circumstances it can present as meningitis or with a stroke affecting the brain or spinal cord (meningovascular syphilis). Late neurosyphilis primarily affects the CNS parenchyma, and occurs beyond early latent syphilis, years to decades after the initial infection.

\section{Les directives du Réseau des laboratoires de santé publique du Canada sur le diagnostic de la neurosyphilis au Canada}

La neurosyphilis désigne l'infection du système nerveux central par le Treponema pallidum à tout stade de la maladie. Elle est classée de diverses façons, y compris précoce ou tardive, asymptomatique ou symptomatique, infectieuse ou non infectieuse. La neurosyphilis tardive touche principalement le parenchyme du système nerveux central et se manifeste après une syphilis latente précoce, des années ou même des décennies après l'infection initiale. Des syndromes cliniques s'y associent, y compris la parésie générale, le tabes dorsalis, la perte d'acuité visuelle et auditive et les manifestations psychiatriques. Des algorithmes différents sont recommandés pour les patients infectés ou non infectés par le VIH, car les manifestations sérologiques et céphalorachidiennes des patients immunodéprimés peuvent différer de celles des patients immunocompétents. Les tests de détection des anticorps incluent le VDRL et le FTA-Abs, tandis que pour certains prélèvements, la réaction en chaîne de la polymérase peut servir de test de détection du T. pallidum. Ce chapitre traite des directives sur les types de prélèvement et leur collecte et présente deux algorithmes qui peuvent être utilisés auprès des hôtes immunodéprimés et immunocompétents à l'aide des tests offerts au Canada. Il contient également une analyse de la réponse thérapeutique et du suivi des tests de laboratoire.

Associated clinical syndromes include general paresis, tabes dorsalis, vision loss, hearing loss and psychiatric manifestations.

\section{Indications for lumbar puncture}

As a lumbar puncture is not without risk, the decision to perform this procedure needs to be carefully considered. Patients in any of the following categories with positive syphilis serology should be strongly considered for a lumbar puncture (9-11):

- Congenital syphilis

- Presence of neurologic or ophthalmic manifestations

- Tertiary syphilis

- Patients who fail to achieve an adequate response to treatment

- Monitoring neurosyphilis treatment response

- In addition to the above, CSF exam should be considered in HIV-infected patients with:

- Serum RPR titre $\geq 1: 32$ dilutions OR

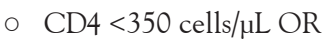

- Some experts recommend CSF examination in all HIV-infected individuals with any stage of syphilis OR

${ }^{1}$ Public Health Agency of Canada, Ottawa, Ontario; ${ }^{2}$ Alberta Provincial Laboratory for Public Health, Calgary, Alberta; ${ }^{3}$ McMaster University,

Hamilton, Ontario; ${ }^{4}$ Hopital Dr George Dumont, Moncton, New Brunswick; 5 Saskatchewan Disease Control Laboratory, Regina,

Saskatchewan; ${ }^{6}$ Institut national de santé publique du Quebec-LSPQ, Sainte-Anne-de-Bellevue, Quebec

*Denotes section lead

Correspondence: Dr Tom Wong, Public Health Agency of Canada, Second Floor, Room 2391, Building 6, 100 Eglantine Driveway, Tunney's

Pasture, Ottawa, Ontario K1A OK9. Telephone 613-946-5700, fax 613-941-9813, e-mail tom.wong@phac-aspc.gc.ca 


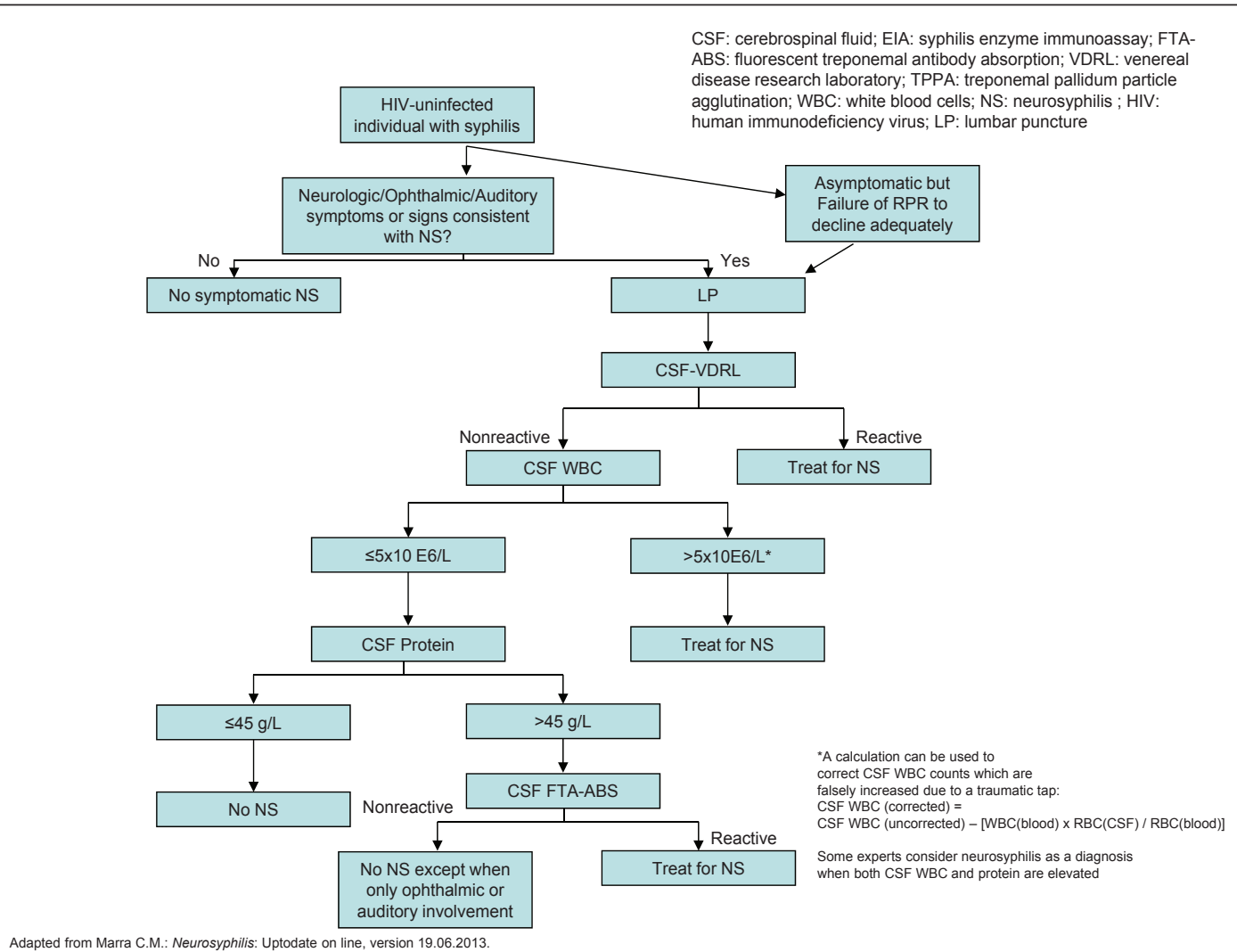

Figure 1) Suggested algorithm for testing and treating HIV-uninfected individuals with suspected neurosyphilis

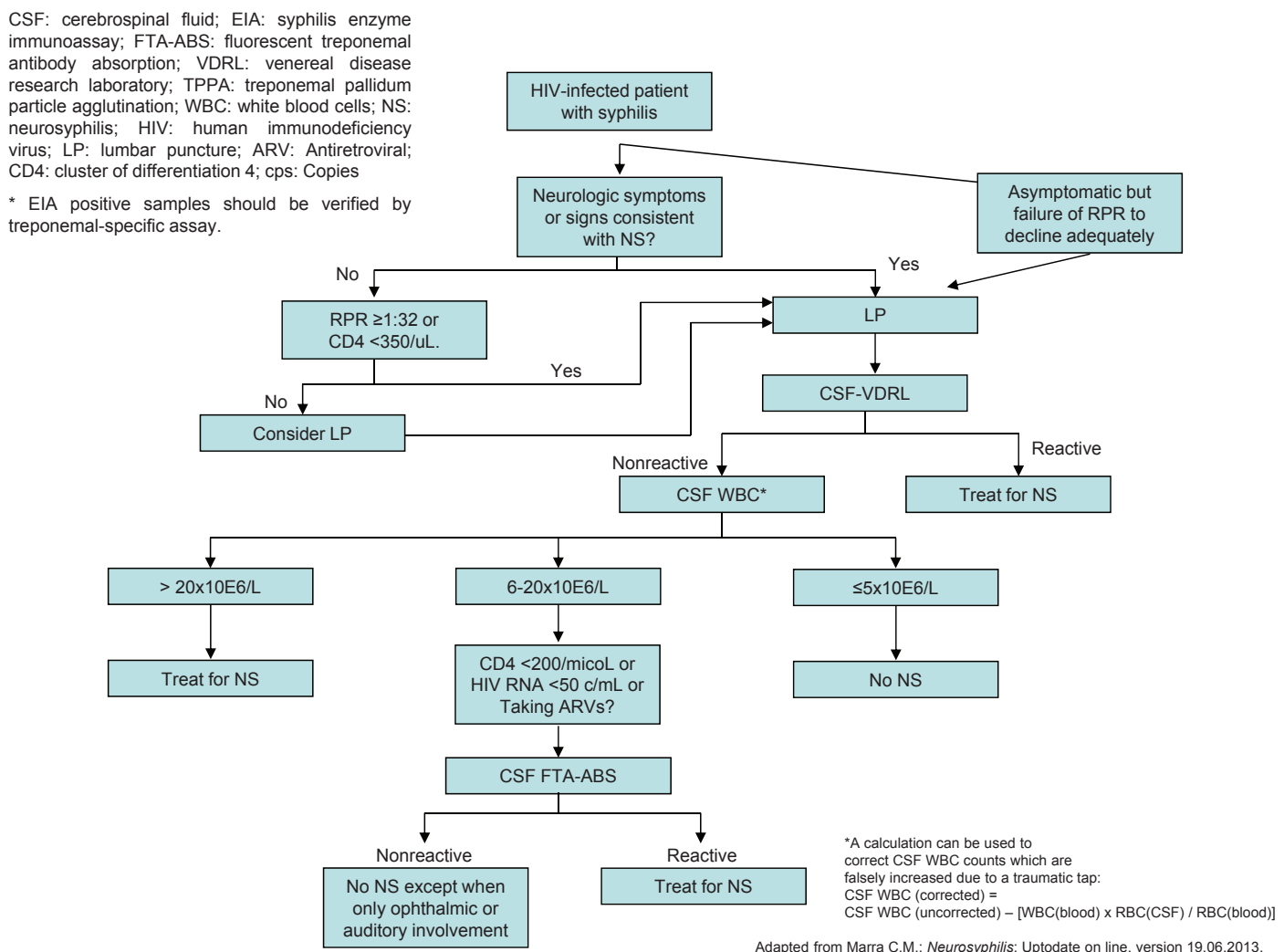

Figure 2) Suggested algorithm for detection and treatment of HIV-infected individuals with suspected neurosyphilis 
TABLE 1

\begin{tabular}{|c|c|c|}
\hline CSF test/parameter ${ }^{*}$ & Abnormal values & Normal range \\
\hline$\overline{\operatorname{VDRL}^{\dagger}}$ & Reactive & Non-reactive \\
\hline WBC count & $>5 \times 10^{6} / \mathrm{L}$ & 0 to $5 \times 10^{6} / \mathrm{L}$ \\
\hline Protein & $>45 \mathrm{~g} / \mathrm{L}$ & 0.15 to $0.45 \mathrm{~g} / \mathrm{L}$ \\
\hline
\end{tabular}

*In the immunocompetent patient; ${ }^{\dagger}$ Due to the low sensitivity of this test, a nonreactive result should not solely be used to exclude a diagnosis of neurosyphilis; ${ }^{\ddagger} A$ calculation can be used to correct CSF white blood cell (WBC) counts that are falsely increased due to a traumatic tap: CSF WBC (corrected) $=$ CSF WBC (uncorrected) $-($ WBC [blood $] \times R B C[C S F] / R B C[$ blood $]$ )

- Late latent syphilis OR

- To rule out other differential diagnosis

\section{TESTING ALGORITHMS FOR NEUROSYPHILIS}

Patients who are HIV-infected and with low CD4 counts may present with serological and CSF findings that are different from immunocompetent hosts (12). Hence, two separate algorithms, adapted from Marra (13), are presented below:

\section{Algorithm for HIV-uninfected patient (Figure 1)}

The entry point for this algorithm is usually a serodiagnosis of syphilis (see Serology chapter) Serologically positive patients with clinical signs and symptoms consistent with neurosyphilis (including ocular and auditory manifestations) should have a CSF examination performed (11). Note, however, that CSF examination is frequently normal in patient with auditory involvement (14). Whenever the eye and/or ear is involved, the patient is managed as a neurosyphilis infection regardless of CSF findings (15). Criteria for asymptomatic neurosyphilis have not been standardized and have been applied inconsistently in research studies $(8,15)$.

Patients with a reactive CSF-VDRL test are to be treated for neurosyphilis. As well, patients with a CSF white cell count of $\geq 5 \times 10^{6} / \mathrm{L}$ should also be treated due to the poor sensitivity of the CSF-VDRL test and the association between abnormal CSF cell counts and neurosyphilis. Some authors (11) also suggest that patients with a high CSF protein (>45 mg/dL) should have their CSF tested by the FTA-ABs assay, a treponemal-specific test, because it is more sensitive that the CSFVDRL. If the FTA-Abs gives a positive result, this is highly suggestive evidence for neurosyphilis, especially if the patient has features compatible with neurosyphilis, which is often a difficult diagnosis to make given the protean nature of this disease. However, these and other authors also recognize the lower specificity of the FTA-Abs assay relative to the VDRL, thus emphasizing the application of sound clinical judgment in making a diagnosis of neurosyphilis. The use of CSF Treponema pallidum particle agglutination assay (TPPA) needs further validation with adequate sample size before recommendations can be made (16). In patients in whom there is some evidence to suggest a clinical diagnosis of neurosyphilis, but the CSF parameters are indeterminate, consultation with a syphilis expert should be sought.

\section{Algorithm for HIV-infected patient (Figure 2)}

As with an immunocompetent patient, the entry point is usually a serodiagnosis of syphilis (see Serology chapter). However, in some patients, the treponemal-specific markers can be indeterminate, inconclusive or, in rare cases, negative, especially if the patient is extremely immunocompromised (12). These factors should be considered when determining whether to proceed with a lumbar puncture, especially in the absence of supporting clinical signs and symptoms. Serologically positive patients with clinical signs and symptoms consistent with neurosyphilis should have a CSF examination performed, as should asymptomatic HIV-infected patients with a serum RPR titre at least $1: 32$ or patients with a CD4 count $<350$ cells/ $\mu \mathrm{L}$ (17). HIV itself is associated with mild CSF pleocytosis and mild elevation of CSF protein. Patients with a reactive CSF-VDRL, as well as those with a CSF white cell count $\geq 20 \times 10^{6} / \mathrm{L}$, should be treated for neurosyphilis using the recommended treatment regimens. In light of the insensitive CSF-VDRL assay, some experts propose that HIV-infected patients with a CSF white cell count between $6 \times 10^{6} / \mathrm{L}$ and $20 \times 10^{6} / \mathrm{L}$ and at high risk for neurosyphilis be treated for neurosyphilis even when the CSF-VDRL is negative.

\section{CSF COLLECTION REQUIREMENTS AND INTERPRETATION}

The blood-CSF barrier is a physical and physiological one, resulting in differences in the concentration between many macromolecules between these two compartments. In Table 1, adult normal ranges are provided, and these parameters vary for different infectious and noninfectious diseases.

The numbers of tubes required to process all of the tests may vary among laboratories. The suggested sequence, number and volumes of CSF per tube is provided below (check with local laboratory for details):

- CSF cell count and differential count $(1 \mathrm{~mL})$ and differential count CSF total protein $(1 \mathrm{~mL})$,

- CSF VDRL (and FTA-Abs)* (1 mL) T pallidum PCR (1 mL)

*Since CSF samples should be free of visible red blood cells, the second or third aliquots should be tested in the VDRL and FTA-Abs assays. The presence of red cells may signify a traumatic tap, which could adversely affect the interpretation of these assays.

Once CSF is collected it should be kept cool but not frozen prior to testing. The cell count and protein should be determined as soon as possible after the lumbar puncture, due to cell lysis on prolonged storage. If the request is not urgent, samples for VDRL testing can be stored for up to one week in the fridge (approximately $4^{\circ} \mathrm{C}$ ) before being tested, after which they should be stored frozen at $-20^{\circ} \mathrm{C}$ or below. Samples for molecular testing should be stored at $-70^{\circ} \mathrm{C}$ as soon as possible if testing is not available within approximately five days (18).

\section{LABORATORY TESTS (TABLE 1)}

Tests available for syphilis detection can be divided into antibody and direct detection methods. Antibody assays include the time-honoured VDRL assay and the FTA-Abs. PCR for T. pallidum can be used as direct detection assays for some specimens.

\section{VDRL (Venereal Disease Research Laboratory)}

This is a non-treponemal assay requiring a light microscope to view the flocculation reaction adequately. Heat inactivation of CSF is not required prior to the VDRL assay. All qualitative positive CSF samples should be diluted two-fold in saline to obtain an endpoint for quantitative comparison. The endpoint titre is the last dilution to show a reactive result (19). Appropriate positive and negative controls have to be included to verify the accuracy of the assay.

The specificity of the CSF VDRL is high (99.8\%) whereas its sensitivity is approximately 50\% (range 30\% to 70\%) (8). Consequently, while a negative CSF VDRL does not exclude neurosyphilis, a positive finding is strongly suggestive of the disease. Rare false-positive VDRL results do occur and additional testing such as FTA-ABs may be an alternative verification assay, together with serological verification of syphilis infection. Patients who are serologically negative for syphilis but have a positive CSF VDRL are unlikely to have neurosyphilis. An additional advantage of this assay is that because it is quantitative, changing titres can be used to monitor the effectiveness of treatment.

\section{CSF FTA-ABS (Fluorescent Treponemal antibody - absorbed)}

This is a highly sensitive treponemal-based assay, which utilizes the principle that treponemal-specific antibodies in serum or CSF will attach to corresponding antigenic sites of T. pallidum organisms fixed on a slide. In turn, reagents containing fluorescent conjugated anti-human antibody will bind to those on the organism thus allowing visualization of the spirochetal morphology when viewed by fluorescence microscopy. Consequently, this assay is subject to a number of limitations such as nonspecific fluorescence and operator subjectivity (20). When dealing with CSF samples, it is particularly important to prevent contamination with serum or plasma because the high sensitivity of the FTA-Abs assay can 
detect very low levels of contaminating serum antibody. Thus, the presence of any red cells is a key indicator of a possible contamination and lumbar puncture should be repeated. The role of this assay is still debated.

Despite effective treatment, the CSF FTA-Abs can continue to be positive for an extended period. In serial follow-up testing of treated patients, CSF FTA-Abs assay is not useful (21).

\section{CSF Treponema pallidum particle agglutination assay (TPPA)}

This is a treponemal assay primarily used for confirmation of syphilis treponemal antibody in serum samples. Some clinicians $(16,17)$ have proposed the use of this assay as an alternative to the FTA-Abs assay. In two studies, this CSF assay performed similar to the CSF FTA-Abs, with both assays identifying true cases of neurosyphilis, based upon a reactive VDRL result. However, both also identified antibody in some control patients with no evidence of neurosyphilis, thus again emphasizing the value of exercising clinical judgment in making this diagnosis in isolation from all the laboratory and clinical information.

The TPPA does not seem to have found general use in many clinical laboratories, as part of the protocol is to calculate a serum-to-CSF ratio or index (22), which may not always be possible if a matched blood sample is not drawn at that time of the lumbar puncture.

\section{CSF INNO-LIA}

This is a line blot immunoassay that has been applied to the confirmation of treponemal antibody in plasma or serum. This assay has been applied to the determination of treponemal antibody in CSF in a single article (23). While this assay was able to detect the presence of antibody in patients with neurosyphilis, there was no control group to serve as a comparison. Consequently, this assay is still a research tool rather than a diagnostic tool.

\section{CSF T pallidum PCR}

This molecular detection of treponemes in CSF was published by Hay et al (24) in 1990. Subsequent studies have shown that this assay is not as sensitive as the rabbit infectivity assay that can detect as few as one to two viable treponemes whereas at least 10 organisms are needed for PCR positivity. Although available, this assay is generally restricted to reference facilities. At this stage, PCR is not a sensitive enough tool for the routine detection of T. pallidum in serum or CSF. If CSF tests positive for $T$. pallidum in a well-validated assay, this result is definitive for the presence of the organism.

\section{RESPONSE TO TREATMENT}

In addition to clinical monitoring, serum RPR should be monitored at (1), three, six, 12 and 24 months for immunocompetent individuals, and HIV-infected individuals should be monitored more frequently, at three, six and 12 months, and yearly thereafter in accordance with the Canadian Guidelines for Sexually Transmitted Infections (10). Those with abnormal CSF findings should have follow-up CSF at sixmonthly intervals until normalization of CSF parameters.

In adults, CSF pleocytosis is generally the first measure of improvement and a decline should occur over approximately six months. The CSF-VDRL titre should decline (fourfold within a year) if it is initially high, but it may take years to revert to negative (25). A persistent, low CSF-VDRL titre after a course of treatment may warrant retreatment, but if CSF pleocytosis and elevated protein levels have resolved and serum VDRL titre has not risen, additional treatment is unlikely to be beneficial (26). Elevated protein levels, if present, will begin to decline during the first six months but can take up to two years to return to normal (27). CSF protein may decline more slowly in patients who are neurologically abnormal compared with those who are neurologically normal (28). A normalization of serum RPR is predictive of normalization of CSF and clinical abnormalities after treatment of neurosyphilis (29). If the CSF cell count has not decreased after six months or if the CSF improvement is sub-optimal after two years, retreatment should be considered (10).

All CSF laboratory parameters normalize more slowly in patients co-infected with HIV (28). The possibility of treatment failure should be considered if there is clinical progression or an increase in RPR/ VDRL by $\geq 2$ dilutions at any time or if CSF pleocytosis fails to resolve two years post-therapy.

DISCLOSURES: The authors have no conflicts of interest to declare.

\section{APPENDIX 1}

Clinical findings associated with neurosyphilis (30)

\begin{tabular}{|c|c|c|}
\hline Diagnosis & Symptoms & Signs \\
\hline Asymptomatic & None & \\
\hline \multirow[t]{15}{*}{ Parenchymatous neurosyphilis } & General paresis & Emotional lability \\
\hline & 15-20 years after primary infection & Loss of short-term memory \\
\hline & & Slurred speech \\
\hline & & Lack of attention to personal appearance \\
\hline & & Psychotic delusional state, especially megalomania, "general paresis of the insane" \\
\hline & & Hyperactive reflexes \\
\hline & & Argyll Robertson pupils \\
\hline & Tabes dorsalis & Shooting or lightning pains in the extremities \\
\hline & 25-30 years after primary infection & Loss of position sense in the lower extremities \\
\hline & & Impotence \\
\hline & & Urinary and fecal incontinence \\
\hline & & Wide based ataxic gait with footslap \\
\hline & & Argyll Robertson pupils \\
\hline & & Romberg's sign \\
\hline & & $\begin{array}{l}\text { Cranial nerve disturbances such as loss of facial expression and tremors of lips, } \\
\text { tongue and facial muscles }\end{array}$ \\
\hline \multirow[t]{4}{*}{ Meningovascular neurosyphilis } & Weeks to years after primary infection & Neck stiffness \\
\hline & & Generalized or focal seizures \\
\hline & & Aphasia \\
\hline & & Hemiplegia or hemiparesis \\
\hline Ocular disturbances & Weeks to years after primary infection & $\begin{array}{l}\text { Iridocyclitis, episcleritis, vitreitis, retinitis, retinal detachment, progressive concentric } \\
\text { constriction of visual fields with normal visual acuity ("gunbarrel sight") }\end{array}$ \\
\hline Syphilitic otitis & Weeks to years after primary infection & Asymmetric deafness \& tinnitus \\
\hline
\end{tabular}




\section{REFERENCES}

1. Brandt AM: Shadow on the land. In: No Magic Bullet: A Social History of Venereal Diseases in the United States since 1880. New York: Oxford University Press, 1987.

2. Moore J. Studies in asymptomatic neurosyphilis 11 . The classification, treatment and prognosis of early asymptomatic neurosyphilis. Bull Johns Hopkins Hosp 1922;33:231-46.

3. Wile UJ, Stokes JH. A study of the spinal fluid with reference to involvement of the nervous system in secondary syphilis. J Cutan Dis 1914;32:607-623.

4. Wile UJ, Marshall CH. A study of the spinal fluid in one thousand eight hundred and sixty-nine cases of syphilis in all stages. Arch Derm Syphilol 1921;3:272-278

5. Clark G, Danbolt N. The Oslo study of the natural history of untreated syphilis: An epidemiologic investigation based on a restudy of the Boeck-Bruusgaard material a review and appraisal. J Chronic Dis 1955;2:311-44

6. Ghanem KG. REVIEW: Neurosyphilis: A historical perspective and review. CNS Neurosci Ther 2010;16:e157-68.

7. Marra CM. Update on neurosyphilis. Curr Infect Dis Rep 2009; 11:127-34.

8. Golden MR, Marra CM, Holmes KK. Update on syphilis: Resurgence of an old problem. JAMA 2003;290:1510-4.

9. Ghanem KG, Moore RD, Rompalo AM, Erbelding EJ, Zenilman JM, Gebo KA. Lumbar puncture in HIV-infected patients with syphilis and no neurologic symptoms. CID 2009;48:816-2.

10. PHAC. Canadian Guidelines for Sexually Transmitted Infections, Syphilis Chapter, January 2010.

11. CDC. Sexually transmitted diseases guidelines, 2010. MMWR Recomm Rep 2010:59(RR12):1-116

12. Johnson PD, Graves SR, Stewart L, Warren R, Dwyer B, Lucas RC. Specific syphilis serological tests may become negative in HIV infection. AIDS 1991;5:419-23.

13. Marra CM. Neurosyphilis. Uptodate. Version Feb 18, 2010.

14. Becker GD. Late syphilis hearing loss: A diagnostic and therapeutic dilemma. Laryngoscope 1979;89:1273-88.

15. O'Donnell JA, Emery CL. Neurosyphilis: A current review. Curr Infect Dis Rep 2005; 7:277-84s.

16. Castro R, Prieto ES, Aguas MJ, et al. Evaluation of the Treponema pallidum particle agglutination technique (TP.PA) in the diagnosis of neurosyphilis. J Clin Lab Anal 2006;20:233-8.

17. Marra CM, Critchlow CW, Hook EW 3rd, Collier AC, Lukehart SA. Cerebrospinal fluid treponemal antibodies in untreated early syphilis 1995;52:68-72.
18. Deisenhammer F, Bartos A, Egg R, et al. Guidelines on routine cerebrospinal fluid analysis. Report from an EFNS task force. Eur J Neurol 2006;13:913-22.

19. Creighton ET. Venereal disease research laboratory (VDRL) slide tests, pgs 77-89. In: Larsen SA, Hunter EF, Kraus SJ, eds. A manual of tests for syphilis, $8^{\text {th }}$ edn. Washington, DC: American Public Health Association, 1990.

20. Hunter EF. Fluorescent treponemal antibody-absorption (FTAABS) test, pgs 129-40. In: Larsen SA, Hunter EF, Kraus SJ, eds. A manual of tests for syphilis, $8^{\text {th }}$ edn. Washington, DC: American Public Health Association, 1990.

21. van Eijk RVW, Wolters EC, Tutuarima JA, et al. Effect of early and late syphilis on central nervous system: Cerebrospinal fluid changes and neurological deficit. Genitourin Med 1987;63:77-82.

22. Luger A, Schmidt BL, Steyrer K, Schonwald ES. Diagnosis of neurosyphilis by examination of the cerebrospinal fluid. Br J Vener Dis 1981;57:232-7.

23. Kotnik V, Jordan K, Stopinsek S, Simcic S, Potocnik. Intrathecal antitreponemal antibody synthesis determination using the INNOLIA syphilis score. Acta Dermatoven APA 2007;16:135-41.

24. Hay PE, Clarke JR, Strugnell RA, Taylor-Robinson D, Goldmeier D. Use of the polymerase chain reaction to detect DNA sequences specific to pathogenic treponemes in cerebrospinal fluid. FEMS Microbiol Lett 1990;56:233-8.

25. Dattner B, Thomas EW, De Mello L. Criteria for the management of neurosyphilis. Am J Med 1951;10:463-7.

26. Jordan KG. Modern neurosyphilis - a critical analysis. West J Med 1988;149:47-57.

27. Flores JL. Syphilis. A tale of twisted treponemes. West J Med 1995; 163:552-9.

28. Marra CM, Longstreith WT Jr, Maxwell CL, Lukehart SA. Resolution of serum and cerebrospinal fluid abnormalities after treatment of neurosyphilis. Influence of concomitant human immunodeficiency virus infection. Sex Transm Dis 1996;23:184-9.

29. Marra CM, Maxwell CL, Tantalo LC, et al. Normalization of serum rapid plasma reagin titer predicts normalization of cerebrospinal fluid and clinical abnormalities after treatment of neurosyphilis. Clin Infect Dis 2008:47:893-9.

30. Sparling PF, Swartz MN, Musher DM, Healey BP. Clinical manifestions of syphilis. In: Holmes LL Sparling PF, Stamm WE, et al, eds. Sexually Transmitted Diseases, 4th edn. New York: McGraw Medical, 2008. 


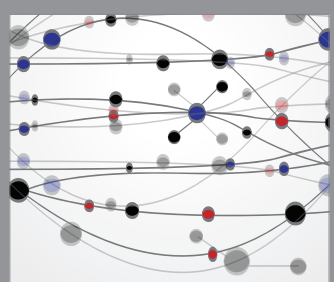

The Scientific World Journal
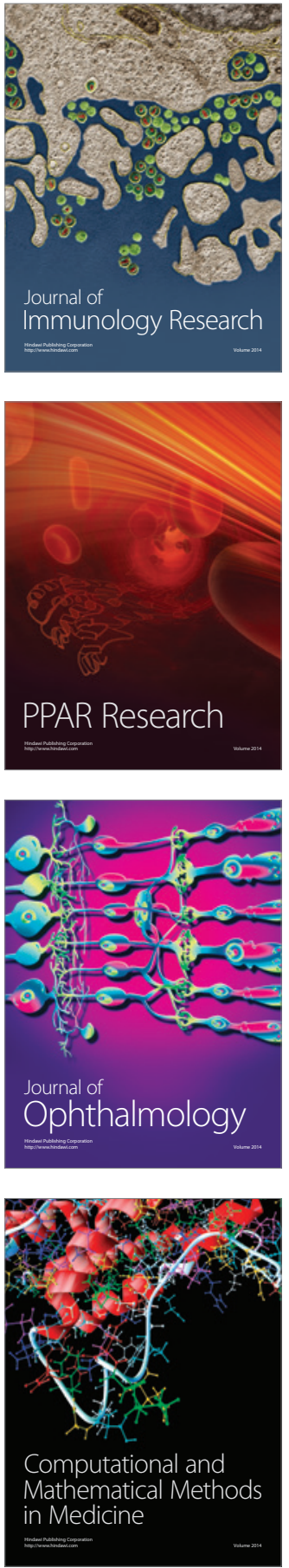

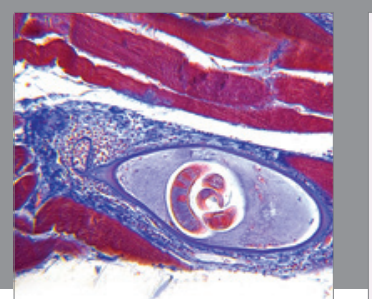

Gastroenterology Research and Practice

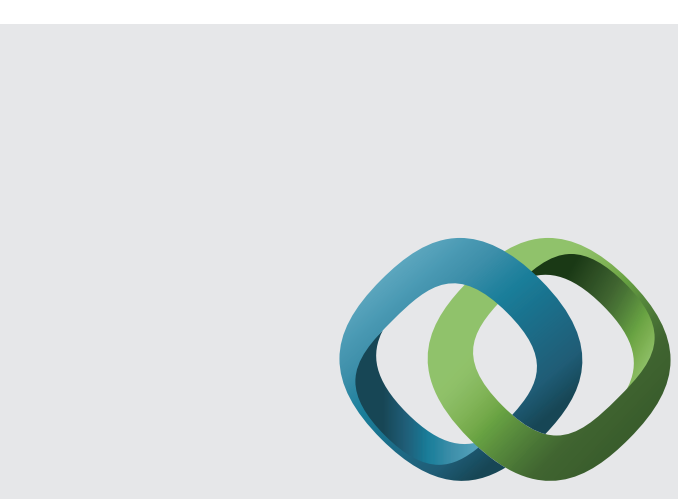

\section{Hindawi}

Submit your manuscripts at

http://www.hindawi.com
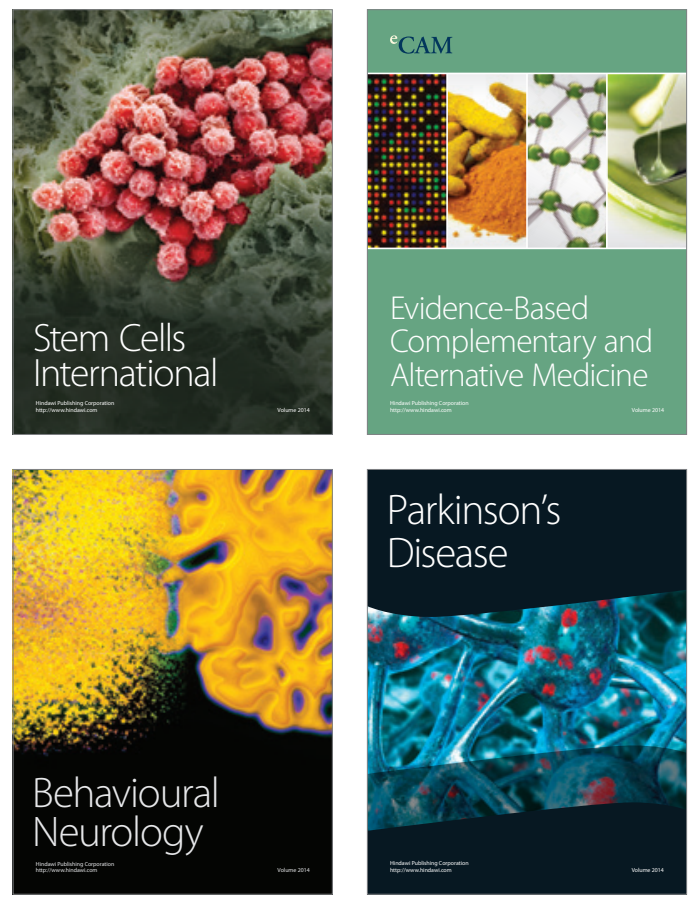
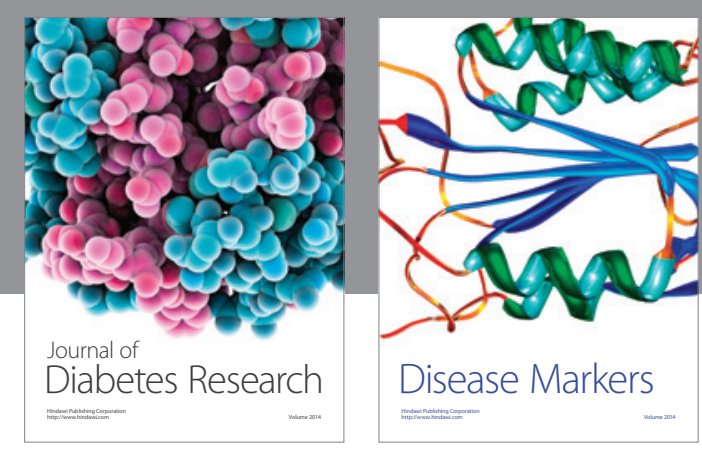

Disease Markers
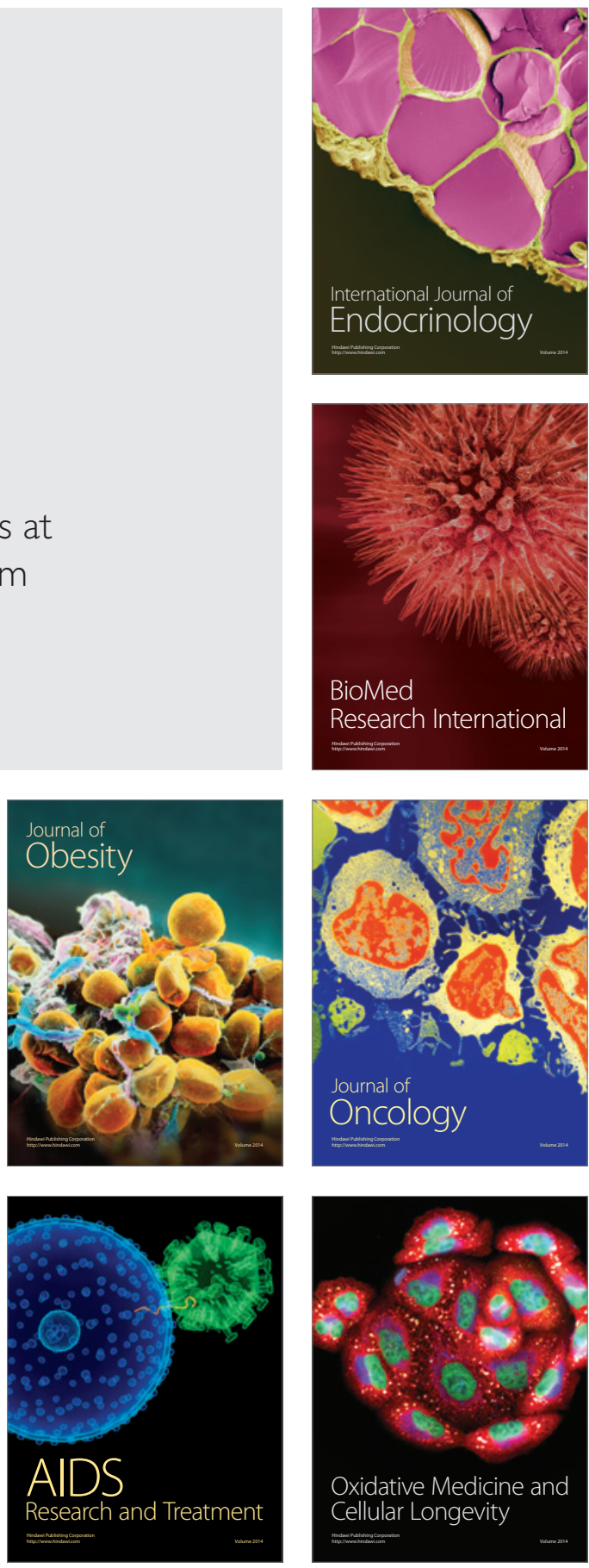